\title{
Optimal aquifers and reservoirs for CCS and EOR in the Kingdom of Saudi Arabia: an overview
}

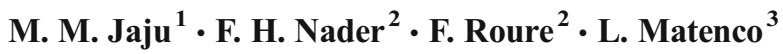 \\ Published online: 22 August 2016 \\ (C) The Author(s) 2016. This article is published with open access at Springerlink.com
}

\begin{abstract}
An overview on the tectono-stratigraphic framework of the Arabian plate indicates obvious differences between two distinct areas: the hydrocarbon-prolific sector and non-hydrocarbon-prolific sector. These differences resulted from the interplay of a variety of factors; some of which are related to the paleo-geographic configuration (eustatic sea level fluctuations, climatic conditions, and salt Basins), others to differential subsidence (burial) and structural inversions. During the Paleozoic, the regional compression was caused by far field effects of the Hercynian orogeny. This led to major folded structures in central and eastern Saudi Arabia (e.g. Ghawar anticline). During the Mesozoic, the most important tectonic factor was the stretching of the crust (extension), accompanied with the increase in temperature, resulting in an increase of the accommodation space, and thicker sedimentary successions. Regional unconformities are mostly found where folded structures are dominant, and they acted as a carrier systems for the accumulation of hydrocarbon and groundwater. A good understanding of the stratigraphy and tectonic evolution is, thus, required to develop carbon capture and storage (CCS) and to design efficiently enhanced oil recovery (EOR) in both sectors. Oil and gas reservoirs offer geologic
\end{abstract}

This article is part of the Topical Collection on Arabian Plate: Lithosphere Dynamics, Sedimentary Basins and Geohazards

M. M. Jaju

marwan.jaju@gmail.com

1 School of Geosciences, University of Aberdeen, Aberdeen AB24 3UE, UK

2 Geosciences Division, IFP Energie nouvelles, Rueil-Malmaison, France

3 Department of Earth Sciences, Utrecht University, Utrecht, The Netherlands storage potential as well as the economic opportunity of better production through $\mathrm{CO}_{2}$-EOR. The world greatest hydrocarbon reservoirs mainly consist of Jurassic carbonate rocks, and are located around the Arabian Basin (including the eastern KSA and the Arabian Gulf). The Cretaceous reservoirs, which mainly consist of calcarenite and dolomite, are located around the Gotnia salt Basin (northeast of KSA). Depleted oil and gas fields, which generally have proven as geologic traps, reservoirs and seals, are ideal sites for storage of injected $\mathrm{CO}_{2}$. Each potential site for $\mathrm{CO}_{2}$-EOR or CCS should be evaluated for its potential storage with respect to the containment properties, and to ensure that conditions for safe and effective long term storage are present. The secured deep underground storage of $\mathrm{CO}_{2}$ implies appropriate geologic rock formations with suitable reservoir rocks, traps, and impermeable caprocks. Proposed targets for CCS, in the non-hydrocarbon-prolific sector, are Kharij super-aquifer (Triassic), Az-Zulfi aquifer (Middle Jurassic), Layla aquifer (Late Jurassic), and Wasia aquifer (Middle Cretaceous). Proposed targets for EOR are Safaniya oil field (Middle Cretaceous) (Safaniya, Wara and Khafji reservoirs), Manifa oil field (Las, Safaniya and Khafji reservoirs) (Late Jurassic), and Khuff reservoir (Late PermianEarly Triassic) in central to eastern KSA.

Keywords Tectono-stratigraphy $\cdot$ Hydrocarbon/ non-hydrocarbon-prolific sectors $\cdot$ Paleoclimate $\cdot$ EOR \& CCS $\cdot$ Arabian plate $\cdot \mathrm{KSA}$

\section{Introduction}

The Arabian plate extends from the eastern Mediterranean region to the western Zagros thrust zone, and comprises the whole Arabian Peninsula. It is enclosed by latitude $13^{\circ}$ and $38^{\circ} \mathrm{N}$ and longitudinal $35^{\circ}$ and $60^{\circ} \mathrm{E}$. The 


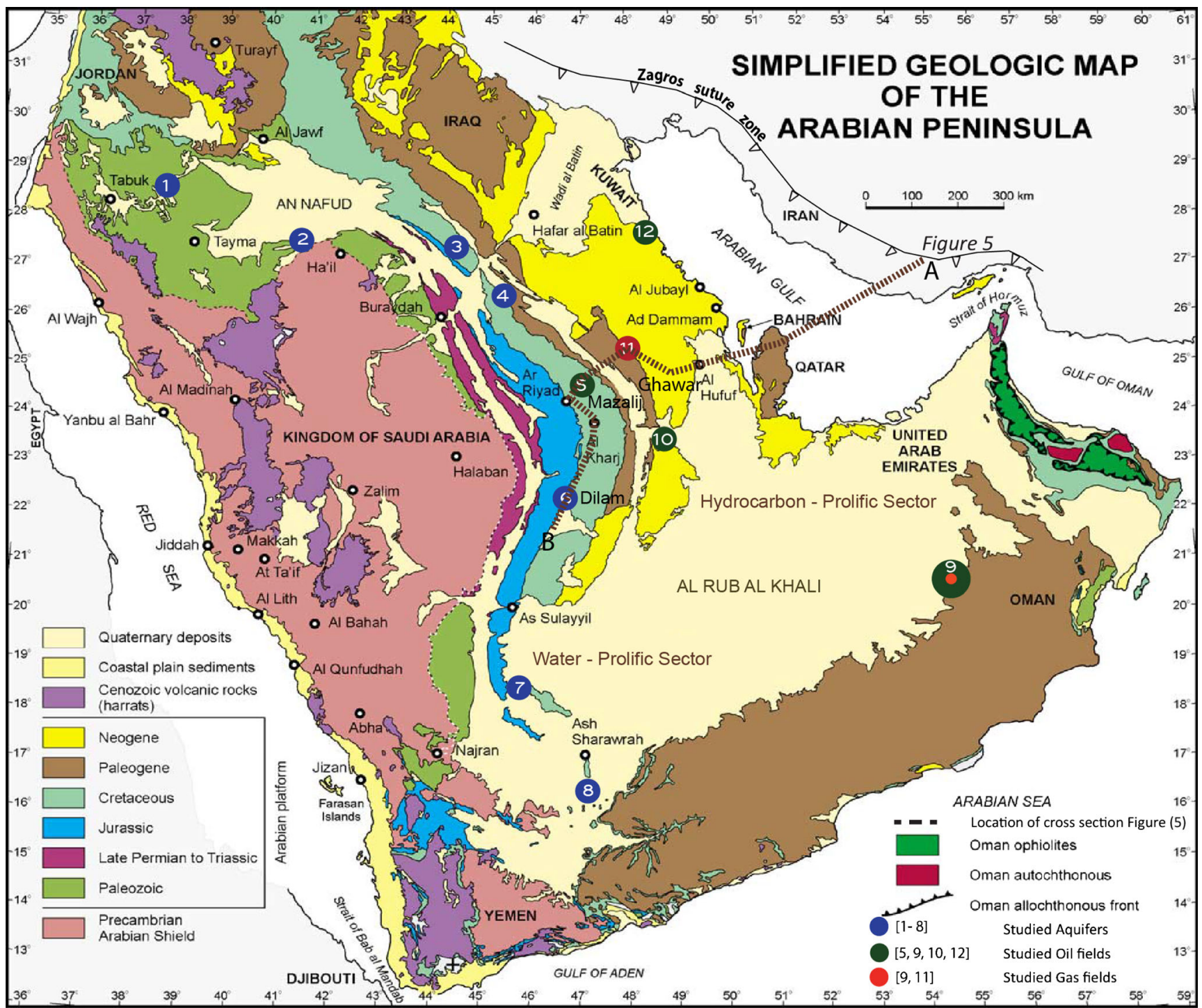

Fig. 1 Simplified geological map of the Arabian Peninsula, showing the studied hydrocarbon wells, aquifers and the regional cross section A-B of Fig. 5 location. (After Le-Nindre et al. (2003))

Arabian plate is subdivided in distinct geologic domains, i.e. the Arabian Shield in the west, the Arabian platform into the Center and the Arabian Gulf in the east. The study area covers the Kingdom of Saudi Arabia (KSA), which constitutes most of the Arabian plate (Fig. 1).

A comprehensive literature review of previous work and the general geology of the KSA were first conducted. It covered issues related on the geodynamics, tectonics, stratigraphy, paleoclimate, sea-level variations, hydrogeology, hydrostratigraphy, petroleum systems, and petro-physical properties of the rock formations, [i.e., Powers et al., 1966; Beydoun, 1991; Cole et al., 1994; Stump and Van Der Eem, 1995; Al-Sharhan and Narin, 1997; Al-Aswad and Al-Bassam, 1997; AlBassam et al., 2000; Sharland et al., 2001; Zeigler, 2001; Le-Nindre et al., 2003; Pollastro, 2003; Haq and
Al-Qahtani, 2005; Bell and Spaak, 2007; and Rahman and Khondaker, 2012].

In order to summarize and analyze the vast wealth of available information, 12 synthetic lithostratigraphic columns were compiled representing the main oil productive and non-oil productive sectors (Fig. 2). Eight sites are located between the Tabuk area in the northwest and Ash-Sharawarh in the southwest across Wajid area (Figs. 1 and 2). The four other

Fig. 2 Twelve synthetic lithostratigraphic columns, representative of the main hydrocarbon productive and non-hydrocarbon productive sectors in the Arabian plate. The main unconformities in both sectors are illustrated. (Data compiled from [Morton, 1959; Powers et al., 1966; McClure, 1978; Murris, 1980; Wilson, 1981; Bazanti, 1988; Cole et al., 1994; Stump and Van Der Eem, 1995; Al-Sharhan and Narin, 1995, 1997; Cagatay, et al., 1996; Oterdoom et al., 1999; Jones and Stump, 1999; Al-Shayea, 2000; Pollastro, 2003 and Al-Ramadan et al., 2004]) 


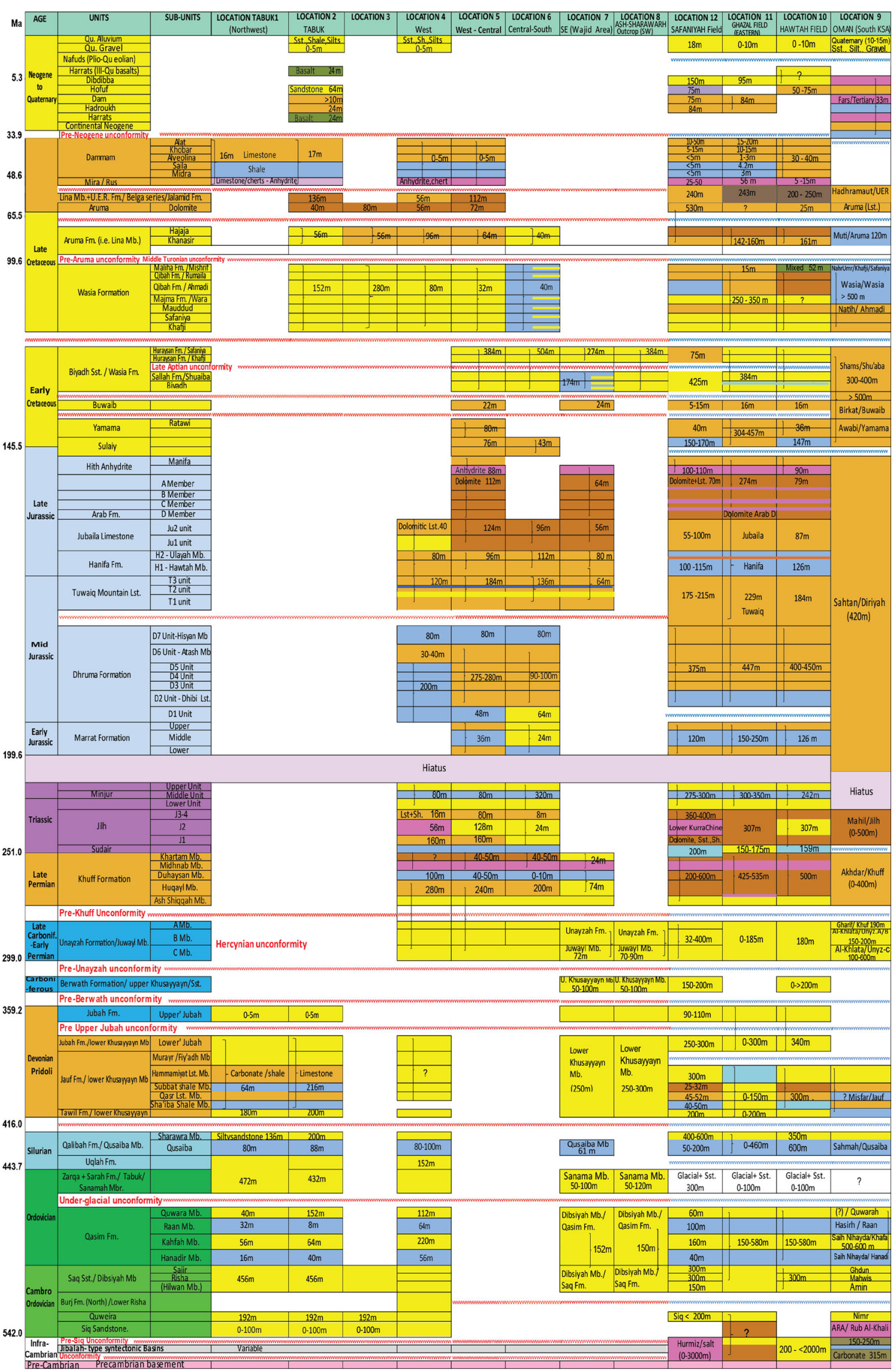


sites are located between Safaniyah in the northeast and Oman in the southeast, and include the Ghawar area (Figs. 1 and 2).

Geo-sequestration of $\mathrm{CO}_{2}$ is burdened with systematic risks, which relates to the geological characteristics of the site, nature and efficiency of reservoirs, underlying and overlying impervious formations, and the prevailing fluid-flow regimes [Kaldi, 2008; Barkto et al., 2009; and Taglia, 2010]. Understanding the links between tectonics and stratigraphy, throughout a large, geological time-scale, is believed to help in defining such major factors (listed above) that affects the success of $\mathrm{CO}_{2}$ underground storage and eventually, associated EOR.

First, a stratigraphical model is proposed including most of aquifers and reservoirs in the study area (i.e., the KSA). Then, we identify, in this contribution, the potential rock units suitable for long term application of $\mathrm{CO}_{2}$ sequestration and reservoirs which could be used for enhanced oil recovery (EOR), in order to reduce anthropogenic greenhouse gases, and their effects on global climate change.

\section{Geological setting}

Based on generalized plate-scale chronostratigraphy charts, unconformities, sea level variation, climate and the paleogeographic location of the plate across geological times, the impacts of paleoclimate and tectonic activity on depositional environments and hydrocarbon evolution can be highlighted. The Paleozoic rock series have been characterized, accordingly, through two distinct cycles.

During an early Paleozoic cycle (Cambrian-OrdovicianSilurian), the Arabian plate was first located near the equatorial line in the Cambrian time, resulting in a relatively warmer climate, and an increase in the accommodation space due to induced sea level variation. This coincided with rifting, extension, at the northern Gondwana margin [Konert et al., 2001] (Fig. 3). In the Ordovician, the Arabian plate drifted toward the south latitudes and that coincided with several tectonic pulses. Consequently, collision tectonics led to major uplifts (e.g., Oman), and affected considerably sedimentary and facies patterns [Oterdoom et al., 1999; Al-Jallal and Al-Sharhan, 2005] (Fig. 4). The Arabian plate continuously moved toward the South Pole until it reached the latitude of $55^{\circ}$ [Konert et al., 2001]. Here, the paleoclimate witnessed an expansion of major continental ice sheets in Ashgillian time, and the effects of late Ordovician glaciations [El-Ghali, 2005], which reached eastward, from Jordan through western Saudi Arabia [McClure, 1978]. This remained until the Silurian, when the whole plate returned to the equatorial line. It was accompanied with the increase in temperature, resulting in deglaciation and sea level rise, consequently source rock (hot shale) deposited in anoxic conditions [McClure, 1978].
The late Paleozoic cycle (Carboniferous-Permian-Early Triassic), started with a remarkable event of erosion and non-deposition driven by the propagation of far field compressional stresses through the area, the "Hercynian event." The Arabian plate moved again toward the South Pole and the paleoclimate started to control the plate-scale depositional processes. Glaciations spanned the Late Carboniferous and ended with return to the equatorial line associated with increased temperatures in the late Permian-early Triassic, coincident with slab pull in the south-facing subduction zone [Konert et al., 2001] (Fig. 3).

Throughout the Mesozoic, the stratigraphic architectures and geometries confined within the Arab Basin, resulted from the sea level fluctuations, due to the effects of eustatic changes or relative uplift and subsidence in the vicinity of the Arabian Arch. Besides, the petroleum systems within this Basin (and the hydrocarbon-prolific sector) are pretty much influenced by such stratigraphic configuration. During the middle Jurassic to early Cretaceous times, the axial zone of the Arabian plate underwent subsidence in both prolific and non-prolific sectors, leading to sea level rise and marine sedimentation covering large areas of the Arabian plate (Fig. 4).

From early to middle Cretaceous, continuous subsidence in the Arabian arch occurred in the hydrocarbon-prolific sector, whereas the Arabian Arch was reactivated and uplifted toward the west in the non-prolific sector. This led to a local sea level fall and deposition of siliciclastic (marine and non-marine series) (Figs. 2 and 4).

Accordingly, there are obvious differences in the tectonic evolution between prolific and non-prolific areas, which could be illustrated through the presence of distinct structural features. In the prolific area (eastern margin of the Arabian Gulf), there are wide spreading of faults due to extension and subsidence, whereas in the western part, uplift structure are dominant and that can be observed by the difference in topography between these two areas. In addition, the thicknesses of the sediments may reflect the related tectonic events, which increase toward the eastern part of Saudi Arabia, and that could be due to the continuing subsidence and deposition, mostly without breaks and evidenced by a decrease of the number of unconformities, whereas in the western part, most of the geological rock formations are thinner, with relatively high amount of unconformities (Figs. 2 and 5).

\section{Water dominant sector (non-hydrocarbon prolific area)}

In the eastern part of Saudi Arabia, where hydrocarbon accumulations are rather lacking, aquifers are mainly Paleogene in age [Bakiewicz et al., 1982], i.e., the Umm Er Radhuma and 


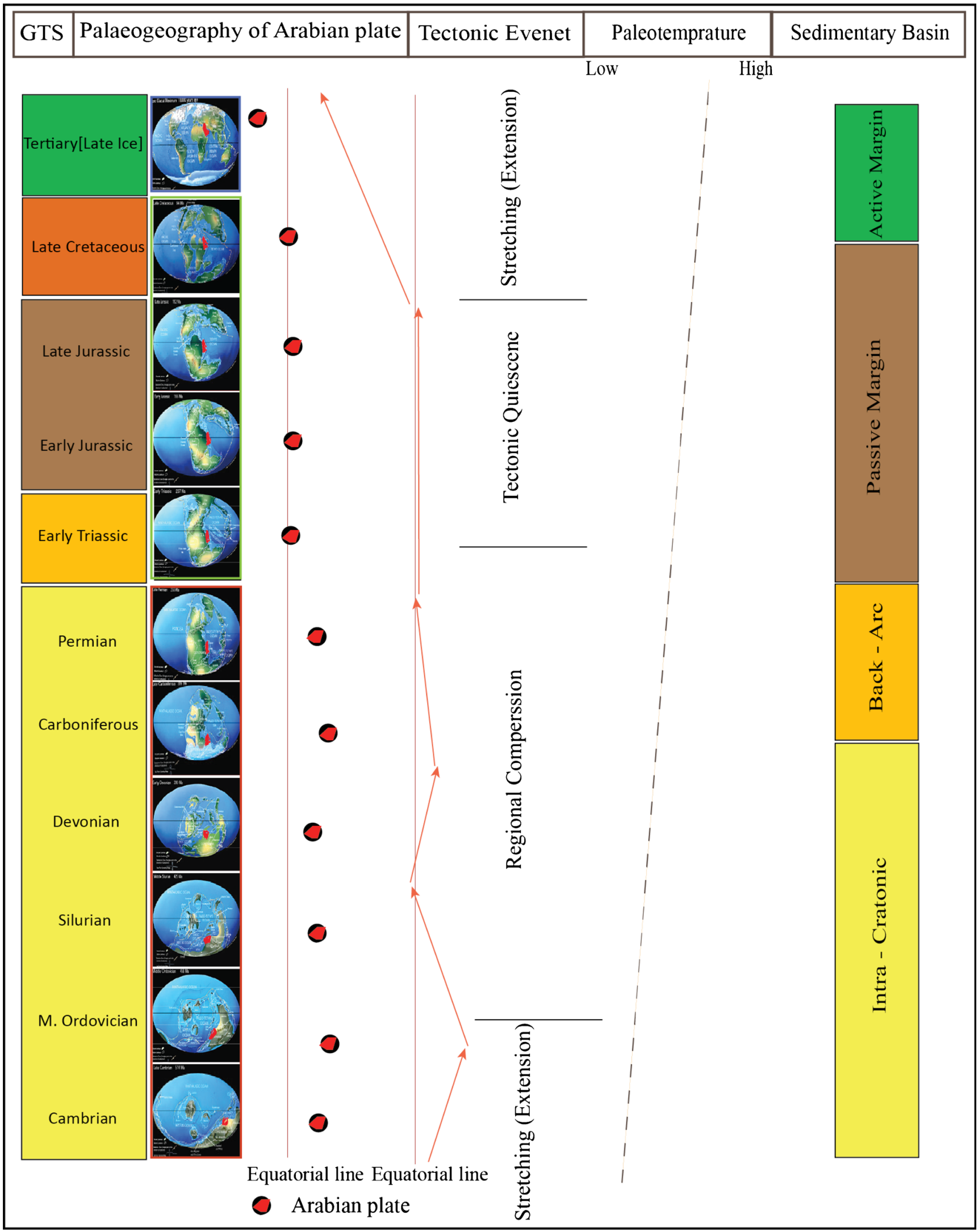

Fig. 3 Conceptual composite figure showing the tectonic drifting of the Arabian plate and Paleoclimate. (Modified from [Brown, 1972 and Scotese, 1998]) 
Fig. 4 Conceptual figure shows the impact of the tectonic activity and the eustatic sea level variations on the Arabian plate evolution across geological times

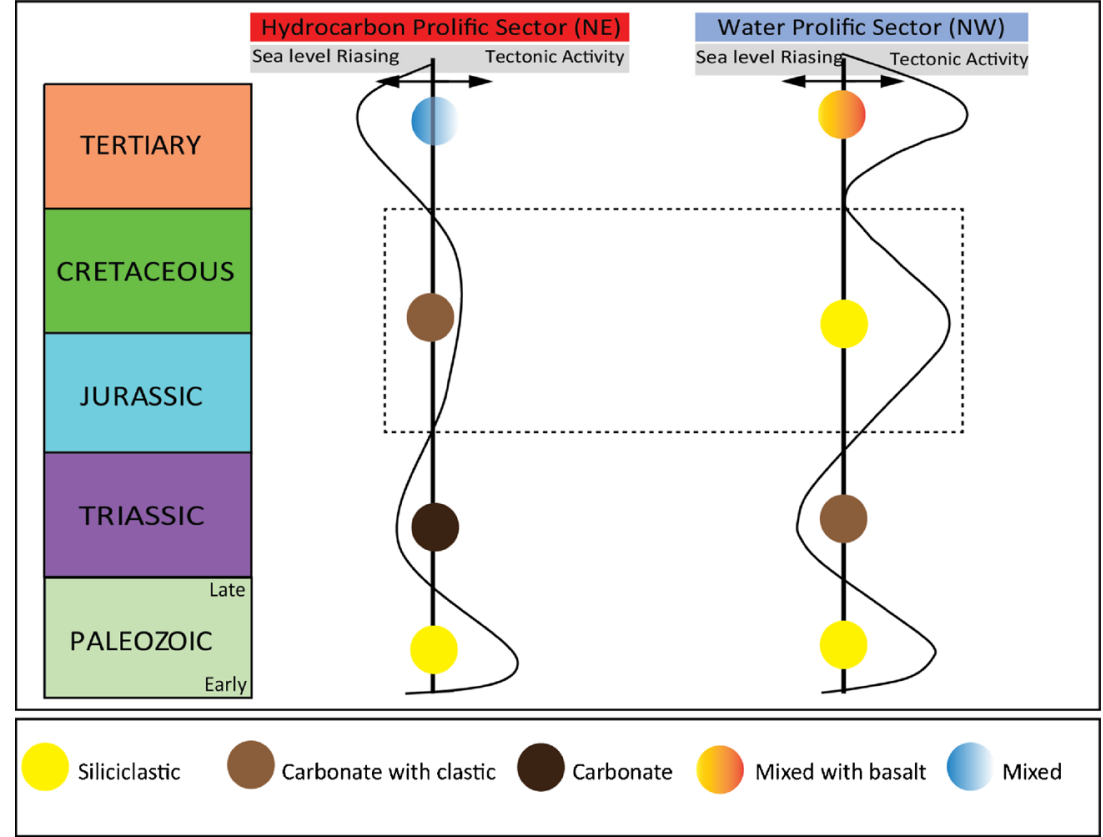

Dammam formations. The Rub'Al-Khali embayment province hosts also such aquifers [Edgell, 1987a]. In northwestern Saudi Arabia, the major aquifer-hosting, tectono-sedimentary Basins are the Tabuk Basin, the Wadi as Sirhan Basin, the Widyan Basin margin and the northeastern interior homocline [Edgell, 1987a, b] (cf. Figure 1).

Al-Aswad and Al-Bassam [1997] have divided the deeper Paleozoic rock series into eight basic aquifer units separated from each other by aquitards. The hydrostratigraphical units of the Mesozoic-Cenozoic in
Saudi Arabia overly the Sudair mega-aquitard [A1Bassam et al., 2000], and the classification proposed by the latter authors was based on the inherent properties of the sedimentary rocks, namely the porosity, permeability, presence of aquitard, thickness and areal extent. Accordingly, based on the combination of large amounts of hydrogeological data from previous published articles and unpublished work, we present a summarized hydrostratigraphical chart of the Arabian plate (Fig. 6).

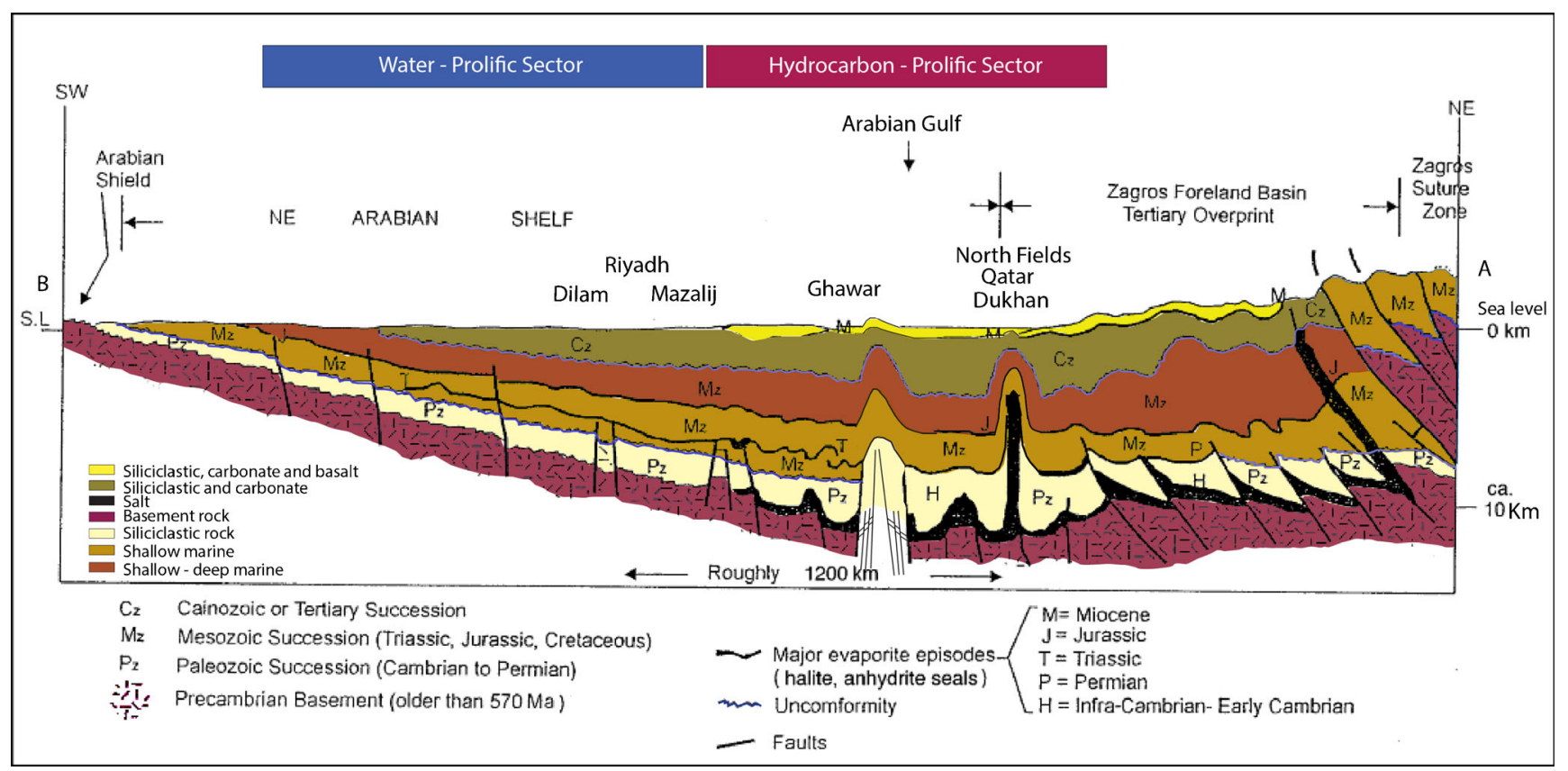

Fig. 5 Schematic section from Zagros suture zone — to Arabian Gulf — to Arabian shield. (Modified from [Beydoun, 1998 and Konert et al., 2001]). For location see Fig. 1 
Fig. 6 The Hydrostratigraphical units of Paleozoic, Mesozoic, and Cenozoic of Saudi Arabia. (Modified from [Al-Ahmadi, 2009; Edgell 1987a, b, 1990; Al-Aswad and Al-Bassam, 1997; Al-Bassam et al., 2000; BRGM, personal communication and Ministry of Agriculture and Water, 1984])

\begin{tabular}{|c|c|c|c|c|c|c|c|c|}
\hline \multicolumn{4}{|c|}{ Chronostratigraphic Units } & Lithostratigraphic Units & \multicolumn{4}{|c|}{ Hydrostratigraphic Units } \\
\hline System & Age/Ma & Serie & & Formation Member & Aquifer & Super Aquifer & Aqua Group & $\begin{array}{l}\text { Aqua } \\
\text { system }\end{array}$ \\
\hline \multirow{3}{*}{$\begin{array}{l}\text { 崫 } \\
\text { 总 }\end{array}$} & \multirow{12}{*}{-67} & \multirow{3}{*}{\multicolumn{2}{|c|}{$\begin{array}{l}\text { MIOCENE } \\
\& \\
\text { PLIOCENE }\end{array}$}} & HOFUF & HOFUF & MESO - & \multicolumn{2}{|l|}{ AQUITARD } \\
\hline & & & & DAM & \multirow{3}{*}{$\begin{array}{c}\text { HASA } \\
\text { AQUIFER }\end{array}$} & \multirow{5}{*}{$\begin{array}{l}\text { HARADH } \\
\text { SUPER- } \\
\text { AQUIFER }\end{array}$} & \multirow{15}{*}{ 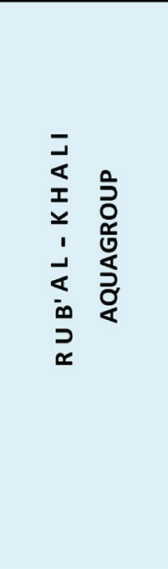 } & \multirow{20}{*}{ 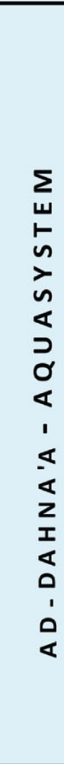 } \\
\hline & & & & HARDUK & & & & \\
\hline 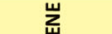 & & \multirow{2}{*}{\multicolumn{2}{|c|}{ EOCENE }} & DAMMAM & & & & \\
\hline 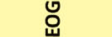 & & & & RUS & & & & \\
\hline 崩 & & \multicolumn{2}{|c|}{ PALEOCENE } & UMM ER RADHUMA & UER AQUIFER & & & \\
\hline \multirow{6}{*}{ 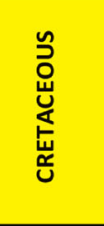 } & & \multirow{4}{*}{\multicolumn{2}{|c|}{$\begin{array}{l}\text { CAMPANIAN } \\
\text { CENOMANIAN } \\
\text { ALPIAN } \\
\text { APTIAN }\end{array}$}} & $\begin{array}{l}\text { ARUMA } \\
\end{array}$ & ARUMA & MESO - AQUIFER & & \\
\hline & & & & WASIA & WASIA AQUIFER & KHURAIS SUPER - & & \\
\hline & & & & BIYADH & \begin{tabular}{|l|} 
BIYAYADH AQUIFER \\
\end{tabular} & AQUIFER & & \\
\hline & & & & BUWAIB & \multirow{2}{*}{\multicolumn{2}{|c|}{ BUWAIB MESO - AQUITARD }} & & \\
\hline & & \multirow{2}{*}{\multicolumn{2}{|c|}{ NEOCOMIAN }} & YAMAMA & & & & \\
\hline & & & & SULAIY & \multirow{5}{*}{\multicolumn{2}{|c|}{$\begin{array}{c}\text { LAYLA } \\
\text { AQUIFER }\end{array}$}} & & \\
\hline \multirow{7}{*}{ 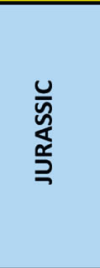 } & & \multirow{5}{*}{\multicolumn{2}{|c|}{ UPPER }} & $\begin{array}{l}\text { Nuvewy } \\
\text { HITH }\end{array}$ & & & & \\
\hline & & & & ARAB & & & & \\
\hline & & & & JUBAILA & & & & \\
\hline & & & & HANIFA & & & & \\
\hline & & & & TUWAYQ MOUNTAIN & TUWAYQ & MESO - & AQUITARD & \\
\hline & & \multicolumn{2}{|c|}{ MIDDLE } & $\begin{array}{l}\text { DWVWVWVWV } \\
\text { DHRUMA }\end{array}$ & AZ ZULFI AQUIFER & & \multirow{4}{*}{ 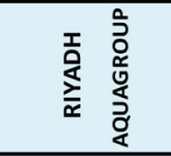 } & \\
\hline & & LOWE & & MARAT & MURAT & MESO - AQUITARD & & \\
\hline & & UPPE & & MINJUR & AL SUWAIDI AQUIFEF & KHARJ & & \\
\hline ทั & & MIDD & & JILH & $\frac{\text { JA'LAH }}{\text { SHAMASIYAH }}$ & SUPER - AQUIFER & & \\
\hline$\frac{\vec{c}}{x}$ & & LOWE & & SUDAIR & SUDAIR & MEGA - & AQUITARD & \\
\hline & -250 & UPPE & & KHUFF & & & & \\
\hline PERMIAN & & LOWE & & & KHUFF AQUIFER & RAFHAH & & \\
\hline CARBONIF. & & UPPE & & UNAYZAH & UNAYZAH AQUITARD & SUPPER - AQUIFER & & \\
\hline & 375 - 3 & UPPE & & 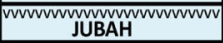 & PADANAH AOUUER & & & \\
\hline$\underline{\underline{4}}$ & & & & HАMMAMIYAT & DADAIVAR AQUITEK] & & 0 & \\
\hline z & & MIDDLE & 岂 & SUBBAT & SUBBAT & MESO - AQUITARD & $3 \frac{0}{4}$ & ш \\
\hline 崫 & $38+28+2$ & & $₫$ & QASR & QASR AQUIFER & & & $\approx$ \\
\hline & & LOWER & & SHA'BA & SHA'IBA AQUITARD & JALAMID & & $\cong$ \\
\hline & -410 & UPPER & & TAWIL & AR'AR AOUUEFR & SUPER - AQUIFER & & 2 \\
\hline$\frac{1}{\alpha}$ & & & & SHARAWRAH & & & & 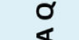 \\
\hline 5 & & LOWER & ș & QUSAIBA & QUSAIBA & MEGA - AQUITARD & & . \\
\hline ติ & 440 & & $\delta$ & $\begin{array}{l}\text { SARAH } \\
\text { SAwwwwwww }\end{array}$ & TAYMA & & & 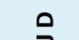 \\
\hline$z$ & & & & QUWARAH & AQUIFER & HAIL & & 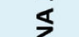 \\
\hline$\frac{\varsigma}{u}$ & 460 & & 5 & RA'AN & RAAN AQUITARD & SUPER - AQUIFER & & \\
\hline z & & |UPPER & $\overline{\mathrm{z}}$ & КАНFAH & KAHFAH AQUIFER & & $\geqslant \frac{\mathscr{v}}{5}$ & \\
\hline مَ & & & & HANADIR & HANADIR & MESO - AQUITARD & $\approx$ & \\
\hline 0 & & LOWER & & SAJIR & SAJIR AQUIFER & & $\bar{\infty} \frac{0}{8}$ & \\
\hline$z_{\leq}$ & -525 & UPPER & & & & SAQ & & \\
\hline 商 & -545 & MIDDLE & $\frac{0}{4}$ & RISHA & RISHA AQUIFER & SUPER - AQUIFER & & \\
\hline$<$ & 570 & LOWER & & & & & & \\
\hline P & ZOTERO & $\mathrm{ZOIC} B$ & ASEN & MENT & ARABIAN & SHIELD & AQUIFU & \\
\hline
\end{tabular}

\section{Hydrocarbon dominant sector}

The major Paleozoic reservoirs of central Arabia are sandstones of the Devonian Jauf and Permian Unayzah formations. Further to the east, in the Arabian Gulf region, the main Paleozoic reservoirs are made up of carbonates of the Upper Permian Khuff formation. Other reservoirs include clastics of pre-Qusaiba sequence that are fault-bounded and sourced laterally by down-faulted Qusaiba shale member. These reservoirs are characteristically affected by silica cementation, which decreases their flow properties [Jones and Stump, 1999].

Many of the Ordovician sandstone reservoirs are sealed by the overlying Lower Silurian Qusaiba shale. The Devonian Jauf sandstone reservoir is sealed by a very distinctive shaly unit called (D3B) in the Ghawar field [Pollastro, 2003]. The impermeable anhydrite, carbonate rocks and shale beds of the Khuff formation and/or equivalent unit, also constitute a major 
regional seal for the central Arabia, Qusaibah Paleozoic sequence. Basal Khuff strata form the top seal to the Permian Unayzah reservoir in Ghawar field.

Traps are mostly structural and related to basement block faulting, tectonic salt movement and deformation (halokinesis) as well as wrench faulting [Pollastro, 2003] (Fig. 7). Generally, in Saudi Arabia and Iraq, the direction of hydrocarbon migration is toward the west [Cole et al., 1994] (Fig. 5).

The best and most prolific Mesozoic reservoirs occur in the Upper Jurassic Arab formation; especially Arab C and $\mathrm{D}$ members, where bulk rock porosity averages $25 \%$ and permeability exceeds 100 md [Edgell, $1987 \mathrm{a}, \mathrm{b}]$. Seal units for the carbonate rock reservoirs of the major Arab formation are made up of anhydrite beds of the upper part of the Arab and Hith formations [Murris, 1980]. Other known reservoirs include the porous carbonate-rock units within the Hanifa and Tuwaiq Mountain formations [Koepnick et al., 1995]. During the middle Cretaceous, regressive sandstones, which are prolific hydrocarbon reservoirs (Wara, Safaniya, Khafji) of the Wasia group, were deposited. They are sealed by Rumailah member which consists of limestone, and Ahmadi member which consists of shale of the Wasia formation.

\section{Long term $\mathrm{CO}_{2}$ sequestration}

The major factors that are believed to influence the sequestration of $\mathrm{CO}_{2}$ as (CCS) in aquifers are: lithology, storage coefficient, transmissivity, porosity, permeability, thickness, depth, TDS, reservoir type, and hydrostratigraphical units (Table 1). Most of these factors were documented and compiled from previously published work during this study, allowing the characterization of the best candidate aquifers with respect to geological sequestration (discussed below).

With respect to prospective geological $\mathrm{CO}_{2}$ sequestration for EOR within producing oil/gas fields in the prolific sector, many issues should be taken into account; such as the source of $\mathrm{CO}_{2}$, chemistry of water, hydrocarbon miscible activity, original oil in place (\% OOIP), depth, dip of the layer, initial pressure, saturation pressure, fracture pressure, and temperature. $\mathrm{CO}_{2}$ displacement processes are highly sensitive to pressure, reservoir type, wetness, heterogeneity, and oil density (API) [i.e. Barkto et al., 2009].

\section{Climatic implications and economic perspectives}

Due to continuously rising global demand for energy, the consumption of fossil fuels is expected to rise through 2035, leading to greater $\mathrm{CO}_{2}$ emissions [International Energy Agency, 2011], CCS technology offers the opportunity to reduce emissions while maintaining a role for fossil fuels in national energy portfolios. The CCS technology has the potential to reduce $\mathrm{CO}_{2}$ emissions from a coal or natural gasfuelled power plant by as much as $90 \%$ [Finkenrath, 2011]; hence, it could provide efficient means for significant reductions of $\mathrm{CO}_{2}$ emissions.

Besides, oil produced by $\mathrm{CO}_{2}$-EOR projects can be considered to be relatively less carbon releasing than oil produced by standard techniques [Taglia, 2010]. Consequently, whether $\mathrm{CO}_{2}$ sequestration is applied through CCS projects into aquifers or as $\mathrm{CO}_{2}$-EOR procedures in old producing fields, the net results are a decrease in anthropogenic greenhouse gases and a globally more economic and cleaner energy production.

\section{Discussion}

The main objectives of this study are to highlight the significance of understanding the tectono-stratigraphic and paleoclimatic evolutions on selecting sites for carbon capture and storage (CCS), and to provide a firsthand inventory of potential targets for $\mathrm{CCS}$ and $\mathrm{CO}_{2-}$ EOR in the Kingdom of Saudi Arabia (KSA). The KSA possesses mature oil and gas fields, which have trapped hydrocarbon for millions of years. They may provide excellent choices for $\mathrm{CO}_{2}$ underground sequestration. Besides, EOR can be achieved by pumping $\mathrm{CO}_{2}$ in some depleting reservoirs, resulting in an economic approach for improving production and decreasing greenhouse gases emissions. Still, some of the deep lying aquifers with low quality groundwater can be also used for CCS, under vast, unpopulated regions (such as the Rub' Al-Khali region).

According to a generalized geological review of the $\mathrm{KSA}$, an easternmost prolific sector and an adjacent westward non-prolific sector have been defined (see above). For instance, obvious changes in thicknesses and lithologies are observed in these two sectors as Saudi Arabia was affected by far-field effects of the Hercynian orogeny.

The non-hydrocarbon-prolific sector belongs to a zone which remained tectonically stable from early Cambrian till late Ordovician. It is characterized by deposition of clastics formations [Siq, Quweria, and Saq sandstones, as well as Qasim (transgressive-regressive cycles)].

During late Ordovician, two glaciations episodes affected the Arabia plate, represented by the Zarqa and Sarah formations [McClure, 1978; Bell and Spaak, 2007].

Then, a new period of increasing temperature due to the move of the Arabian plate toward the equatorial 
Fig. 7 Schematic representation of the major petroleum systems of the Arabian Plate. (Compiled From [Ayres et al., 1982; Benedyczak and Al-Towailib, 1984; Al-Marjeby and Nash, 1986; Al-Husseini, 1991; AbuAli et al., 1999; McGillivrary and Husseini, 1992; Fox and Ahlbrandt, 2002; Al-Ghamdi et al., 2008 and Arouri et al., 2009])

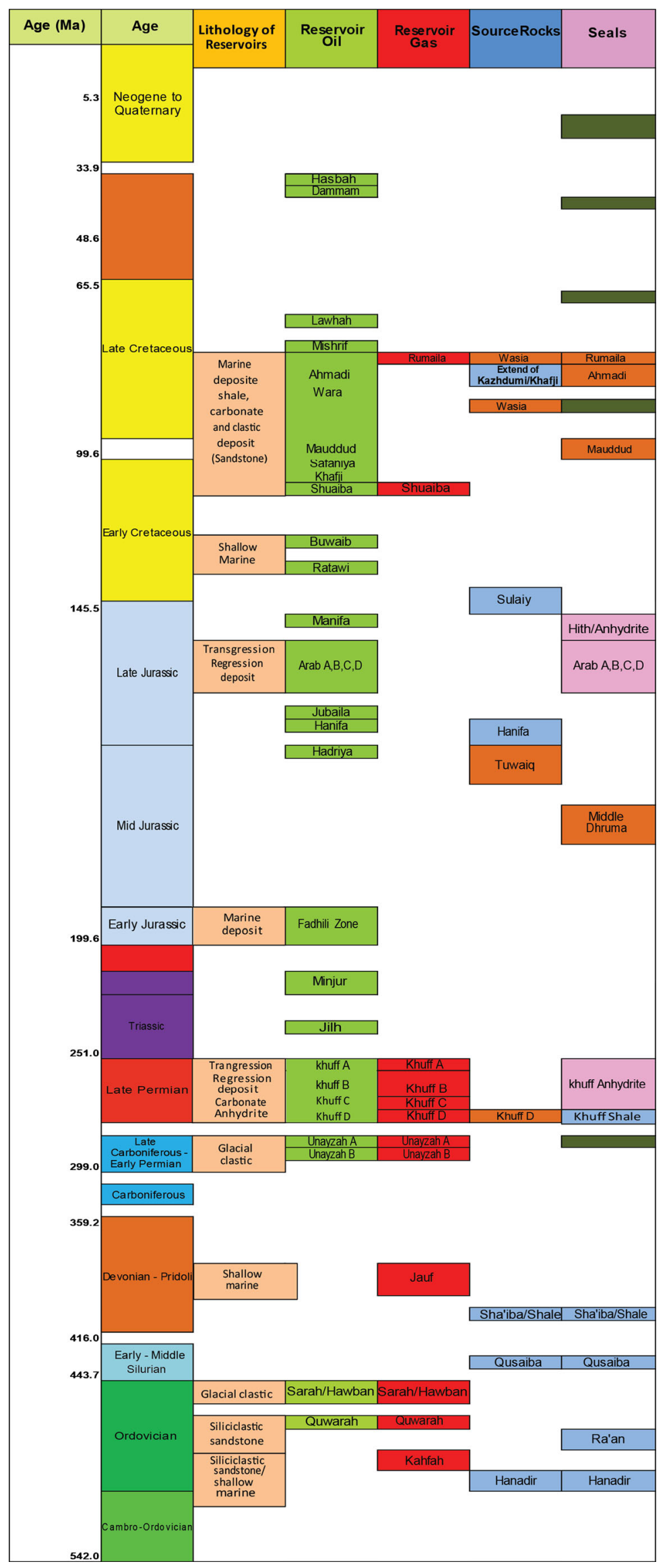




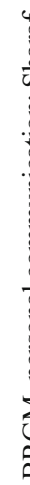
It ,

$$
\text { 竞 }
$$

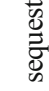

) $=\stackrel{8}{=}$

동ำ

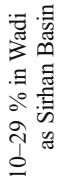

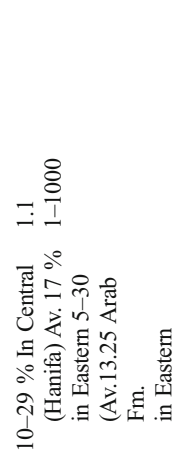

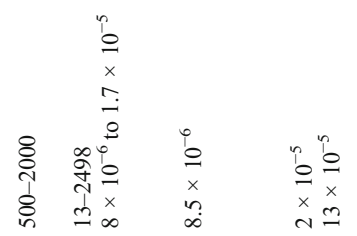

蒙落

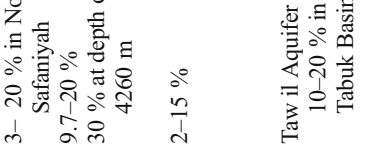<smiles>C1CC1C1CC1</smiles>

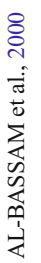

营 专

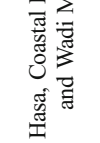

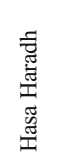

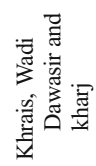

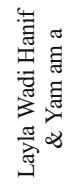

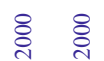

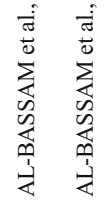

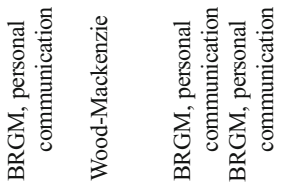

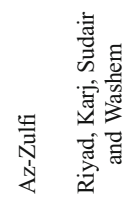

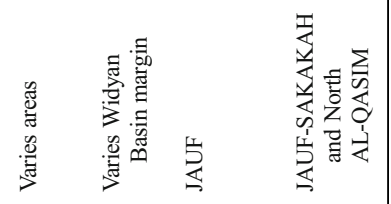

5

\section{8}

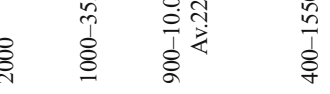

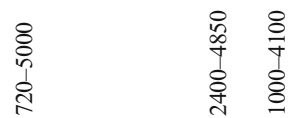

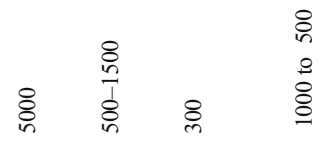

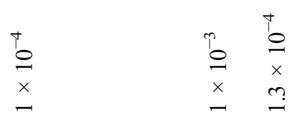

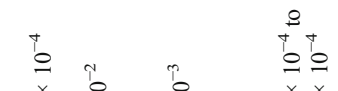

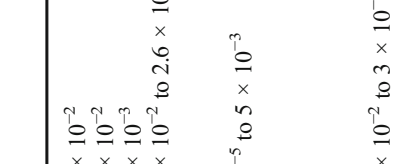

$\begin{array}{lll}x \times x & b & x \\ x m y-1 & 0\end{array}$

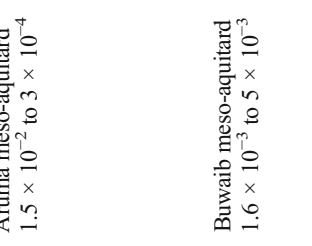

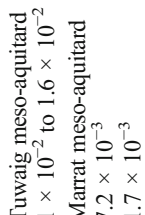

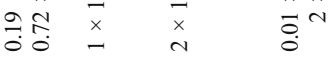

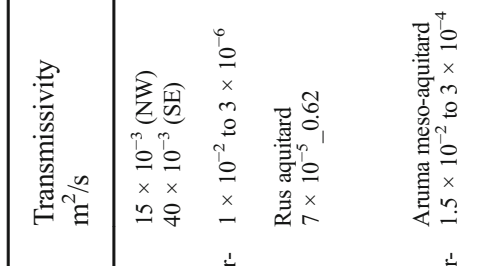

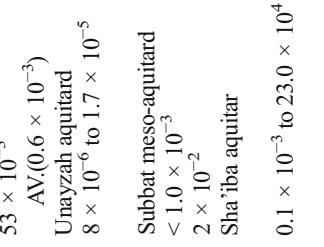

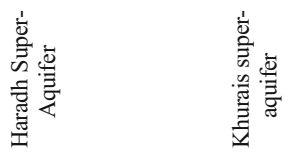

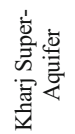

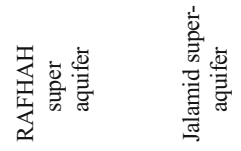

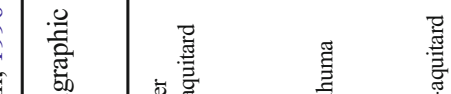

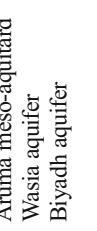

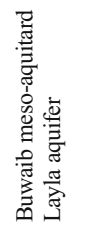
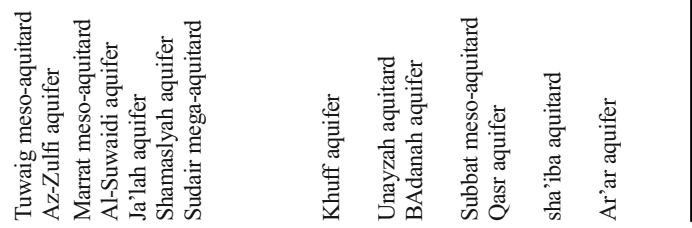
position (Fig. 3). The deposition of the Tawil formation during early Devonian consists of continental clastic sandstone, and middle-late Devonian is recorded by the Jauf formation which consists of carbonate and shale. It was then followed by the late Devonian Jubah formation [Jones and Stump, 1999] (Fig. 2).

Paleozoic carbonate rocks are rare, and in general sandstone is the dominant lithology in the rock formations toward the south (Rub'Al-Khali region). The thicknesses of the Paleozoic formations are almost twice larger in the hydrocarbon-prolific sector (compared to those in the non-prolific sector), which matches with the general northeastward trend of thickening and tilting [Beydoun, 1991, 1998] (Fig. 5). During the Permian, the northern and eastern margins of the plate were affected by rifting (inducing a rise of the asthenosphere) as well as a general increase in surface temperature caused by warmer climatic conditions [Murris, 1980, and Konert et al., 2001]. By mid-Permian time, an eperic carbonate platform was established. Evaporites are present in the central part of the KSA and toward the northeast. Clastic material was mainly derived from the erosion of the western hinterland, with local supplies from the east in the high Zagros [Murris, 1980].

During Early Triassic, hot arid conditions are prevailed over the whole Basin. A coeval increase in clastic influx from the western hinterland is evident. The climate became less arid and there was apparently a relative drop in sea level, caused either by eustatic lowering of the sea level or a rise of the Arabian Arch (Fig. 4). During the Jurassic, high sedimentation rates characterized the transgressive limestone deposits of the Marrat formation (Figs. 3 and 8). A gradual return to more humid climate occurred in the Early Cretaceous (Fig. 3). This led to the disappearance of evaporite from the sedimentary records. The regional sea level dropped, and ramp type deposition prevailed. Whereas the clastic influx was still limited, and restricted to the far southwestern part of Arabia. It was followed by a period of increasing clastic influx represented by the Biyadh formation, which occupied the area from the central-west to the southwestern parts of the Saudi Arabia [Powers et al., 1966]. Clastic influx restricted carbonate production. It was followed by the deposition of the Wasia formation (sandstone with shale), whereas toward the northeast (hydrocarbon-prolific sector) this formation consists mainly of transgressive carbonate and evaporite deposits (Fig. 8).

Differential sea level variations between two sectors are suggested resulting from the re-uplift of the axial zone of the Arabian Arch from early to middle Cretaceous. Hence, a local apparent sea level fall has affected this area (including most of the non-prolific 


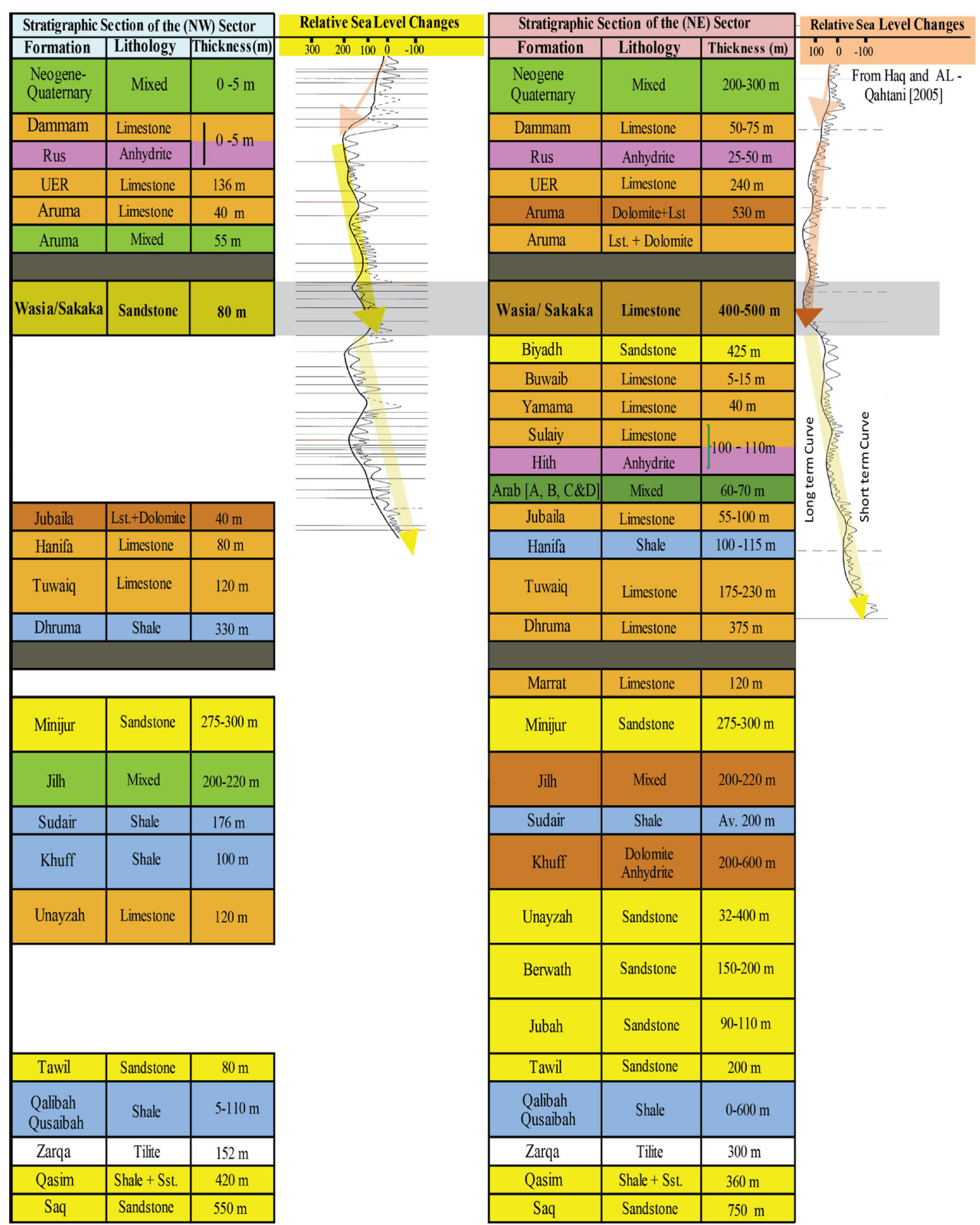

Fig. 8 Simplified stratigraphic sections and sea level variations representing the northwestern and northeastern sectors of the Arabian plate, respectively. (Modified from [Sharland et al., 2001; Haq and Al-Qahtani 2005])

sector) (Fig. 4). In the northeastern area, the subsidence of the Arch was continuous. It started in the middle Jurassic and spanned through middle Cretaceous times, leading to relative sea level rise. With the prevailing humid climatic conditions, different lithologies are observed for the same chronostratigraphic units in the
Cretaceous, as we move from west to east across the Arabian Basin. For instance, the Wasia/Sakaka formation in the northwest are characterized by clastic sandstones deposited on a proximal shelf environment, whereas the same chronostratigraphic unit is made up of relatively deeper carbonate intrashelf facies in the 
northeast (Fig. 8). Furthermore, the overlying Aruma formation (Late Cretaceous) is mainly made up of sandstone in the Tabuk area (northwest of KSA), and grades laterally to carbonate rocks to the northeast, where it accumulates hydrocarbon instead of water as in the Tabuk area (Fig. 8).

The Paleozoic times are supposed to be of lower overall temperatures and higher humidity than the Mesozoic [Konert et al., 2001]. This seems to remain undifferentiated across Arabia. During the Mesozoic, slightly different paleo-climatic conditions appear to have been established in the eastern and western margins of Saudi Arabia; toward the west, temperatures seem to have been lower and a higher humidity prevailed, invoking considerable erosion and weathering.

The Paleozoic rock aquifers have relatively low TDS (mostly lower than $1500 \mathrm{mg} / \mathrm{l}$ ) with lower porosity and permeability values compared to those of the Mesozoic units [Ahmed and Abderrahman, 2008; Saudi geological Survey, n.d.] (Table 1). Accordingly, the major proposed targets for $\mathrm{CCS}$ in the non-prolific regions are Kharij super- aquifer (Triassic), Az-Zulfi aquifer (Middle Jurassic), Layla aquifer (Late Jurassic), and lastly, the Wasia aquifer (Middle Cretaceous).

Extensive studies on the reservoirs properties in the KSA have been achieved for hydrocarbon exploration [e.g., Magara et al., 1992; Sail et al., 1998; Koepnick et al., 1995; Hussain et al., 2006; Sahin et al., 2007; Macrides, and Neves, 2008], compiled the results of these studies with the present geological assessments resulted into proposition of the best targets for EOR (i.e., Safaniya oil field (Middle Cretaceous) (Safaniya, Wara and Khafji reservoirs), Manifa oil field (Las, Safaniya and Khafji reservoirs) (Late Jurassic), and Khuff reservoir (Late Permian-Early Triassic)) in central to eastern the Kingdom of Saudi Arabia.

Unconformities across the Arabian plate constitute an important factor for $\mathrm{CO}_{2}$ storage, because most of them act as a lateral carrier systems which allow higher circulations of fluid (water, gas, and oil). The present study has identified 12 major unconformities (Fig. 2).

\section{Conclusions}

- This study recognized hydrocarbon-prolific sector (mainly reservoirs area) in the northeastern, eastern and central parts of KSA and non-hydrocarbon-prolific sector (mainly aquifers areas) in the western parts of KSA.

- The Paleozoic rock sequences are affected by far field Hercynian orogeny. Relatively thinner rock units with clastics as dominant sediments, prevailed. The Mesozoic rock sequence is affected by extension. Relatively thicker, less unconformities, a smaller number of reservoirs, mainly carbonate sediment, and a relatively higher numbers of seals. It was a period of relative tectonic quiescence, mainly controlled by an increase of temperature and sea level rises.

- The main differences in lithology between the two sectors across the Arabian plate are driven by tectonic inversion operating in the axial part of the central Arabian Arch, which induced uplift and erosion in the western (non hydrocarbon-prolific sector), and relative subsidence in the eastern (hydrocarbon-prolific sector). This is evidenced by the lithology variation of the Wasia formation in the two sectors.

- Proposed targets for CCS, in the non-prolific sector, are Kharij super-aquifer (Triassic), Az-Zulfi aquifer (Middle Jurassic), Layla aquifer (Late Jurassic), and Wasia aquifer (Middle Cretaceous).

- Proposed targets for EOR are Safaniya oil field (Middle Cretaceous) (Safaniya, Wara and Khafji reservoirs), Manifa oil field (Las, Safaniya and Khafji reservoirs) (Late Jurassic), and Khuff reservoir (Late Permian-Early Triassic) in central to eastern KSA.

Open Access This article is distributed under the terms of the Creative Commons Attribution 4.0 International License (http:// creativecommons.org/licenses/by/4.0/), which permits unrestricted use, distribution, and reproduction in any medium, provided you give appropriate credit to the original author(s) and the source, provide a link to the Creative Commons license, and indicate if changes were made.

\section{References}

Abu-Ali MA, Rudkiewicz JL, McGillivray JG, Behar F (1999) Paleozoic petroleum system of Central Saudi Arabia. GeoArabia 4(3):321336

Al-Ahmadi ME (2009) Hydrogeology of the Saq aquifer northwest of Tabuk, northern Saudi Arabia. JKAU: Earth Sci 20(1):51-66

Al-Aswad AA, Al-Bassam AM (1997) Proposed hydrostratigraphical classification and nomenclature: application to the Paleozoic in Saudi Arabia. J Afr Earth Sci 24(4):497-510

Al-Bassam AM, Al-Dabbagh ME, Hussein MT (2000) Application of a revised hydrostratigraphical classification and nomenclature to the Mesozoic and Cenozoic succession of Saudi Arabia. J Afr Earth Sci 30(4):917-927

Al-Marjeby A, Nash D (1986) A summary of the geology and oil habitat of the Eastern Flank hydrocarbon province of South Oman. Mar Pet Geol 3:306-314

Al-Ghamdi, A., Tello, R., and Al-Bani, F., 2008. Collaboration Breeds Success in the Khurais Mega-Project in Saudi Arabia. SPE 120798MS, P. 1-9.

Al-Husseini MI (1991) Potential petroleum resource of the Phanerozoic rocks of Saudi Arabia. SPE, No 24101:1-12 
Al-Jallal, A., and Al-Sharhan, A.S. 2005. Arabia and Gulf. In: Encyclopedia of Geology, Selley, R., Cocks, R. and Plimer, I. (Eds.). Elsevier, P. 140-152.

Al-Ramadan KA, Hussain M, Imam B, Saner S (2004) Lithologic charcteristics and diagenesis of the Devonian Jauf sandstone at Ghawar Field. Eastern Saudi Arabia. Mar Pet Geol 2:1221-1234

Al-Sharhan AS, Narin AEM (1995) Tertiary of the Arabian Gulf: sedimentology and hydrocarbon potential. Paleogeography 114:369384

Al-Sharhan, A.S., and Narin, A.E.M., 1997. Sedimentary Basins and petroleum geology of the Middle East: Amsterdam, The Netherlands, Elsevier Science B.V., P. 1-942.

Al-Shayea NA (2000) Inherent heterogenity of sediment in Dhahran, Saudia Arabia-a case study. Eng Geol 56:305-323

Al-Watban NF (1976) Ground-Water Potentiality of Tabuk and Saq Aquifers in Qasim Region. MSc Thesis, Institute of Applied Geology, KAAU, Jeddah

Alyamani MS, Atkinson TC (1993) Identification of chemical processes using primary component analysis. JKAU Earth Sci 6:135-146

Arouri KR, Al-Saleh SH, Al-Hilal ZM (2009) Residual oil as a tool in migration and filling history analysis of petroleum reservoir, Ghazal Field, Saudi Arabia. Org Geochem 40:617-627

Ayres MG, Bilal M, Jones RW, Slentz LW, Tartir M, Wilson AO (1982) Hydrocarbon habitat in main producing areas, Saudi Arabia. AAPG Bulttein 66(1):1-9

Bakiewicz W, Milne DM, Noori M (1982) Hydrogeology of the Umm Er Radhuma aquifer, Saudi Arabia, with reference to fossil gradients. QJ Eng Geol, Lond 15:105-126

Barkto, K., Al-Shobaili Y., Gagnard, P., Warlick, M., and Baim, A., 2009. Drill Cutting Re-Injection (CRI) Assessment for the Manifa Field: An Enviorenmentally Safe and Coast-Effective Drilling waste Management Strategy. SPE 126077. P. 1-11.

Bazanti, M.S., 1988. Sand Production Model for Safania Field, Saudi Arabia. SPE 19035, P. 1-21, 1988.

Bell, A., and Spaak, P. 2007. Gondwana Glacial Events and their Influence on Petroleum System in Arabia. AAPG International conference. P. 1-4.

Benedyczak, C., and Al-Towailib, A.A., 1984. Offshore Sandstone Reservoir Perforating Practices Used in Saudi Arabia. Journal of petroleum Technology.0149-2136/84/0091-1497. AIM, P. 15111516.

Beydoun ZR (1991) Arabian plate hydrocarbon geology and potential—a plate tectonic approach. American Association of Petroleum Geologist Bulletin student in Geology 33:1-77

Beydoun ZR (1998) Arabia plate oil and gas: why so rich and so prolific. Episodes 21(2):1-8

Brown, G.F., 1972. Tectonic Map of the Arabian Peninsula. Ministry of Petroleum and Mineral Resources. Directorate General of Mineral Resources, Saudi Arabia, Map AP-2.

Cole GA, Abu-Ali MA, Aoudeh SM, Carrigan MJ, Chen HH, Colling EL, Gwathney WJ, Al-Hajji AA, Halpen HI, Jones PJ, Al-Sharidi SH, Tobey MH (1994) Organic geochemistry of the Paleozoic petroleum system of Saudi Arabia. Energy and Fuels 8:1425-1442

Cagatay MN, Saner S, Al-Saiyed I, Carrigan W (1996) Diagenesis of the Safaniya sandstone member (Mid-Cretaceous) in Saudi Arabia. Sediment Geol 105:221-239

Edgell, H.S. 1987b. Geology of Studied Areas. In, KFUPM Ground Water Resources Evaluation in Saudi Arabia, King Fahd University of Petroleum and Minerals, KFUPM Press, Dhahran, P. 24-77.

Edgell, H.S. 1987a. Regional Stratigraphic Relationships of Arabia in Exploration for Oil and Gas. In, Short Course on Hydrocarbon Exploration, KFUPM Press, Dhahran, P. 1-44.

Edgell HS (1990) Geological framework of Saudi Arabia groundwater resources. JKAU Earth Sci 3:267-286
El-Ghali M (2005) Depositional environments and sequence stratigraphy of paralic glacial, paraglacial and postglacial upper Ordovician siliciclastic deposits in the Murzuq Basin, SW Libya. Sediment Geol 177:145-173

Fox, J.E., and Ahlbrandt, T.S. 2002. Petroleum Geology and Total Petroleum Systems of the Widyan Basin and Interior Platform of the Saudi Arabia and Iraq. U.S. Geological Survey Bulletin 2202-E, P. 1-26.

Finkenrath, M. 2011. Cost and Performance of Carbon Dioxide Capture from Power Generation. International Energy Agency

Haq BU, Al-Qahtani AM (2005) Phanerozoic cycles of sea-level change on the Arabian platform. GeoArabia 10(2):127-159

Hussain M, Ahmed SM, Abderrahman W (2008) Cluster analysis and quality assessment of logged water at an irrigation project, eastern Saudi Arabia. J Environ Manag 86:297-307

Hussain M, Hassan WM, Abdulraheem A (2006) Controls of Grian-size distribution on geomechanical properties of reservoir rock - a case study: cretaceous Khafji Member, Zuluf Field, offshore Arabin Gulf. J marpetgeo 23:703-713

International Energy Agency. 2011. "World Energy Outlook Factsheet How will global energy markets evolve to 2035?

Jones PJ, Stump TE (1999) Depositional and tectonic setting of the lower Silurian hydrocarbon source rock facies. Central Saudi Arabia: American Association of Petroleum Geologist Bulletin 83:314-332

Kaldi, J.G., 2008. Geosequestration of $\mathrm{CO}_{2}$ : American Association of Petroleum Geologist, 4, 1-3.

Koepnick, R.B., Lowell, E.W., Kompanick, G.S., Al-Shammery, M.J., and Al-Amoudi, M.O., 1995. Sequences stratal geometries and burial-related microporosity development controls on performance of the Hadriya reservoir(Upper Jurassic) Berri field, Saudi arabia, in al-Husseini, M.I., ed., Geok-94, Middle East Petroleum Geosciences Cponference: Gulf Petrolink, Manama, Bahrain, v. 2, P. 615-623.

Konert G, Afifi AM, Al-Hajri SA, Droste HJ (2001) Paleozoic stratigraphy and hydrocarbon habitat of the Arabian plate. GeoArabia 6: 407-442

Le-Nindre Y-M, Vaslet D, Le-Metour J, Bertrand J, Halawani M (2003) Subsidence modeling of the Arabian platform from Permian to Paleogene outcrops. Sediment Geol 156(2003):263-285

Macrides CG, Neves FA (2008) Lithology estimation from a multicomponent 3D - 4D OPC gulf. 2008. GeoArabia 1:15-33

Magara K, Khan MS, Sharief FA, Al-Khatib HN (1992) Log-derived reservoir properties and porosity preservation of upper Jurassic Arab formation in Saudi Arabia. Mar Pet Geol 10:352-363

McClure HA (1978) Early Paleozoic glaciation in Arabia. Paleogeography, Paleoclimatology, Paleoecology 25:315-326

McGillivrary, J.G., and Husseini, M.I., 1992. The Paleozoic Petroleum Geology of Central Arabia. APPG Bulletin, 76, 10, 1473-1490, 17 Figs.

Ministry of Agricluture and Water (1984) Water atlas of Saudi Arabia. Riyadh, Saudi Arabia, pp. 1-112

Morton DM (1959) The geology of Oman. 5th world petroleum congress. Section 1:1-14

Murris RJ (1980) Middle East: stratigraphic evolution and oil habitat. The American Association of Petroleum Geologists Bulletin 64(5):59761825 Figs

Oterdoom, W.H., Worthington, M., and Partington, M., 1999. Petrological and tectonostratigraphic evidence for a MidOrdovician rift pulse on the Arabian Peninsula: GeoArabia, 4, 467-500.

Pollastro, R.M., 2003. Total Petroleum Systems of the Paleozoic and Jurassic, Greater Ghawar uplift and Adjoining Provinces of Central Saudi Arabia and Northern Arabian- Persian Gulf. U.S. Geological Survey Bulletin 2202-H, P. 1-100.

Powers, R.W., Ramirez, L.F., Redmond, C.D. and Elberg, E.L., 1966. Sedimentary Geology of Saudi Arabia, U.S.G.S. prof. paper 560D, P. 1-147. 
Rahman, S.M., and Khondaker, A.N., 2012. Mitigation measures to reduce greenhouse gas emission and enhance carbon capture and storage in Saudi Arabia: Renewable and Sustainable Energey Reviews, $16,2446-2460$

Sahin A, Ali AZ, Saner S, Menouar H (2007) Permeability anisotropy distributions in an upper Jurassic carbonate reservoir, eastern Saudi Arabia. J Pet Geol 30(2):147-158

Sail IA, Abdulla HM, Magara K (1998) Lith-statistical study of both the Jurassic and cretaceous type section in Saudi Arabia. JKAU; Earth Sci, Sci 1:61-85

Saudi geological Survey: Stratigraphy of the Phanerozoic rocks of Saudi Arabia. Faculty of KSU.sa./21936.

Scotese, C.R., 1998. Quick time computer animations, Paleomap project: Department of Geology, university of Texas at Arlington.
Sharaf MA, Hussein Mt (1996) Groundwater quality in the Saq aquifer, Saudi Arabia. Hydrological Science 41(5):638-696

Sharland, P.R., Archer, R., Casey, D.M., Davies, R.B., Hall, S.H., Heward, A.P., Horbury, A.D., and Simmons, M.D., 2001. Arabian plate sequences stratigraphy: GeoArabia Special Publication 2, Gulf Petrolink, Manama, Bahrain, and P. 1-371.

Stump TE, Van Der Eem JG (1995) The stratigraphy, depositional environments and periods of deformation of the Wajid outcrop belt, southwestern Saudi Arabia. J Afr Earth Sci 21(3):421-441

Taglia, P. 2010. Enhanced oil recovery (EOR) - petroleum resources and low carbon fuel policy in the Midwest.

Wilson, A.O., 1981. Jurassic Arab - C and D carbonate petroleum reservoirs, Qatif field, Saudi Arabia. SPE, P. 171-178. 